\title{
PERANCANGAN ANIMASI SEBAGAI MEDIA PENGENALAN PAKAIAN DAN RUMAH ADAT SUKU MAKASSAR
}

\author{
Nur Idzni Fakhriah HAJ ${ }^{1}$, Baso Indra Wijaya Aziz ${ }^{2}$, Sukarman B ${ }^{3}$ \\ ${ }^{123}$ Desain Komunikasi Visual Fakultas Seni dan Desaim Universitas Negeri Makassar \\ 1idznykaizen@gmail.com \\ 2baso.indra.wa@unm.ac.id \\ ${ }^{3}$ sukarman.b@unm.ac.id
}

\begin{abstract}
ABSTRAK
Pengenalan pakaian dan rumah adat suku Makassar dirasa belum cukup, karena terkadang waktu dan jarak menjadi kendala tersendiri untuk anak dalam mengunjungi objek wisata budaya dan acara- acara yang menampilkan pakaian adat. Observasi serta wawancara yang dilakukan tentang materi pakaian dan rumah adat, didapatkan tidak banyak anak yang mengingat nama dari pakaian adat dan rumah adat tersebut. Oleh karena itu dibutuhkan media informasi alternatif yang dapat membantu dan memudahkan anak dalam mengenal pakaian adat dan rumah adat suku Makassar di Sulawesi Selatan. Perancangan ini bertujuan merancang media pengenalan alternatif berupa video animasi mengenai pakaian dan rumah ada suku Makassar. Pengumpulan data diperoleh melalui studi pustaka, observasi dan wawancara di Dinas Pariwisata dan Kebudayaan Sul-Sel dan Museum Balla Lompoa, data dianalisa dengan metode kualitatif dan teknik analisis matriks. Mengangkat konsep desain 'keceriaan dalam petualangan' dengan fokus materi 'ikon' mengacu pada bentuk pakaian dan rumah adat suku Makassar yang ditampilkan secara sederhana dan ringkas. Visual branding 'kedekatan anak dengan materi' dengan konsep materi pendukung cerita petualangan fantasi. Menampilkan gaya ilustrasi kartun dan gaya animasi 2D limited animation dengan warna-warna cerah (fullcolors), huruf bergaya cursive (Cavorting) pada judul dan isi bergaya sans serif (Calibri). Penelitian ini menghasilkan video animasi yang menceritakan petualangan Sarah dan Daeng Aru dalam dunia Eksploria mengenali pakaian adat dan rumah adat suku Makassar, dengan target audiens anak berusia 9-10 tahun dan gemar menonton. Video Animasi berjudul "Eksploria! Petualangan Sarah dan Daeng Aru di Rumah Nenek" berdurasi 8.31 menit.
\end{abstract}

Kata Kunci: Media Pengenalan; Pakaian Adat; Rumah Adat; Suku Makassar; Animasi.

\section{PENDAHULUAN}

Budaya adalah suatu keseluruhan kompleks yang meliputi pengetahuan, kepercayaan, seni, kesusilaan, hukum, adat istiadat, serta kesanggupan dan kebiasaan lainnya yang dipelajari manusia sebagai anggota masyarakat (Kusherdyana, 2013). Salah satu budaya yang paling mudah terlihat secara fisik adalah pakaian adat dan rumah adat. Pakaian adat adalah pakaian beserta semua kelengkapannya yang dipakai oleh masyarakat di daerah tertentu, sedangkan rumah adat adalah rumah khas yang dimiliki dan digunakan sebagai tempat tinggal suku tersebut (2011). Dalam Undang-Undang nomor 11 tahun 2010, pakaian dan rumah adat masuk sebagai benda dan bangunan cagar budaya. Pada pasal 32 ayat 1 UUD 1945 disebutkan Negara menjamin kebebasan masyarakat dalam memelihara dan mengembangkan nilai-nilai budayanya. Salah satu upaya pelestarian budaya yang dapat dilakukan yaitu dengan mengenalkan secara langsung kepada masyarakat, terutama kepada anak sejak usia dini. Anak yang berperan sebagai generasi penerus bangsa, generasi yang akan mewarisi budaya di masa mendatang, maka penanaman jati diri bangsa sebagai rakyat Indonesia, pengetahuan dan pengenalan akan budaya harus dilakukan.

Provinsi Sulawesi Selatan memiliki beragam budaya, terdiri dari empat etnik besar dan salah satunya adalah suku Makassar. Suku Makassar merupakan suku yang tinggal di bagian selatan pulau Sulawesi Selatan. Secara 
budaya, Suku Makassar memiliki kedekatan dengan suku Bugis yang tinggal di sebelah utara, sehingga warna budaya memiliki kemiripan dengan suku Bugis, yang membedakan hanya pada bahasanya saja. Pengenalan budaya berupa pakaian adat dan rumah adat suku Makassar masih dapat ditemukan seperti pada penggunaan pakaian adat saat mengantarkan undangan pernikahan dan acara besar seperti hari jadi Sul-Sel dan beberapa pemukiman rumah warga yang masih menyerupai rumah adat yang belum dimodifikasi.

Selain itu berdasarkan wawancara yang telah dilakukan di Dinas Kebudayaan dan Pariwisata (disbudpar) Provinsi Sulawesi Selatan, dari pemerintah sendiri telah menyediakan objek wisata budaya berupa museum dan benteng yang di dalamnya juga terdapat replika pakaian adat dan rumah adat, namun untuk pengkhususan media pengenalan kepada anak memang belum disediakan. Adapun secara formal pakaian adat dan rumah adat juga dipelajari di sekolah dasar, sehingga dapat melengkapi pengetahuan anak tentang berbagai macam pakaian adat dan rumah adat.

Akan tetapi, pengenalan tersebut dirasa belum cukup, karena terkadang waktu dan jarak menjadi kendala tersendiri untuk anak dalam mengunjungi objek wisata budaya dan acara- acara yang menampilkan pakaian adat. Selain itu penulis juga melakukan obeservasi kecil dengan mengajukan pertanyan ringan kepada beberapa anak secara acak tentang materi pakaian adat dan rumah adat dan beberapa anak menjawab tidak mengingat nama dari pakaian adat dan rumah adat tersebut. Sehingga penulis menyimpulkan media yang tersedia kurang menarik minat anak dalam mengenal pengetahuan tersebut sehingga anak mudah terlupa dan menurunkan ketertarikannya untuk mengenali pakaian adat dan rumah adat suku Makassar. Maka dari itu, dibutuhkan media informasi alternatif yang dapat membantu dan memudahkan anak dalam mengenal pakaian adat dan rumah adat suku Makassar di Sulawesi Selatan.

Berdasarkan survei SEANUTS tahun 2012 yang menekankan pada gerak aktif anak, sekitar 55,2\% anak menghabiskan waktunya untuk menonton televisi, bermain komputer ataupun game lebih dari 2 jam setiap hari (sinarharapan.com). Tinggi persentase kebiasaan menonton anak ini dapat dijadikan peluang dalam merancang media informasi pengenalan alternatif yang berkaitan dengan kegiatan menonton, misalnya menonton animasi. Saat ini penggunaan animasi bukan sekedar untuk menghibur melainkan juga dapat digunakan ke dalam media edukasi, informasi, iklan, game dan sebagainya. Selain itu pula dalam kajian psikologi, terdapat beberapa fungsi kepribadian anak yang dapat dikembangkan melalui visual yaitu: fungsi pengamatan, fungsi perhatian dan fungsi fantasi/imajinasi. Fungsi tersebut dapat diterapkan ke dalam animasi untuk mengembangkan pemikiran anak dengan menanamkan rasa ketertarikan terhadap budaya yang ada di sekitarnya melalui perwakilan pakaian adat dan rumah adat suku Makassar.

Berdasarkan uraian tersebut maka penulis merencanakan sebuah perancangan animasi yang dapat dimanfaatkan sebagai media pengenalan yang edukatif dan menghibur serta dapat memudahkan anak dalam mengenali pakaian dan rumah adat suku Makassar.

Adapun tujuan perancangan ini adalah merancang sebuah media informasi pengenalan alternatif yang dapat menarik minat anak untuk mempelajari dan mempermudah dalam mengenal pengetahuan tentang pakaian adat dan rumah adat suku Makassar. Berbentuk video animasi dan dengan harapan agar anak menyukai dan mudah mengingat budayanya. Juga merupakan salah satu upaya pelestarian budaya melalui media animasi dan pengenalan kepada masyarakat luas. Manfaat teoritis yang diperoleh bisa menjadi wadah pembantu dalam menjelaskan informasi yang tidak ditampilkan pada media sebelumnya (seperti museum, acara festival, buku pengetahuan umum) dalam mengenalkan pakaian adat dan rumah adat suku Makassar. Manfaat praktis yang diperoleh bagi anak (siswa) dapat menjadi hiburan yang menarik dan menambah wawasan anak. Bagi peneliti, dapat menjadikan materi dan hasil perancangan dalam skripsi ini sebagai referensi dan dapat melakukan pengembangan dari penelitian yang telah penulis lakukan.

Tinjauan desain relevan dalam perancangan ini adalah Perancangan Media Pembelajaran Interaktif Tentang Pakaian Adat 
dalam Bentuk Boneka Tangan Untuk Anak Usia 6-8 Tahun (Lasapu et al., 2015). Dalam jurnal penulis menampilkan tema belajar sambil bermain dan menggunakan metode kualitatif $5 \mathrm{~W}+1 \mathrm{H}$ dengan analisis SWOT pada hasil observasi. Hasil perancangan berupa media pembelajaran (media 3D) boneka dari kain flanel dengan pakaian adat yang bisa diganti-ganti, bersifat interaktif karena dapat ditampilkan dengan cerita menggunakan media dan buku panduan yang disediakan. Materi pengenalan pakaian adat yang ditampilkan yaitu pakaian adat pulau Jawa dan sekitarnya. Perbedaan yang akan dirancang adalah perbedaan media utama berupa video animasi 2D, serupa dengan latar perancangan tersebut mengambil salah satu kegiatan anak yaitu bermain sedangkan penulis mengambil kegiatan menonton. Selanjutnya Perancangan Augmented Reality Rumah Adat Sulawesi Selatan (Caprisa, 2020). Dalam jurnal penulis menampilkan konsep fun atau ceria dengan target audiens 7-12 tahun, bergaya desain simpel dengan warna-warna cerah. Menggunakan metode analisa kualitatif dengan metode penelitian wawancara/survei yang dibahas menggunakan analisis SWOT. Perancangan yang dihasilkan berupa aplikasi augmented reality berbentuk 3D disertai media pendukung berupa buku pendamping marker (jika di scan akan menghasilkan visualisasi 3D rumah adat), X-Banner, stiker, poster dan merchandise. Kendatipun terdapat perbedaan media dan materi komunikasi pengenalan, perancangan ini menampilkan kesamaan materi yaitu rumah adat yang juga berfokus pada bentuk rumah adat yang salah satu materinya adalah suku Makassar. Perbedaan yang akan dirancang adalah perbedaan media utama berupa video animasi 2D, augmented reality hampir serupa menampilkan gambar juga tapi lebih mengunakan bentuk 3D.

Game Edukasi "Ragam Budaya" Sebagai Media Pembelajaran Budaya Tentang Pakaian dan Rumah Adat di Indonesia (Sugiyanto, 2011). Perancangan ini menghasilkan sebuah aplikasi game edukasi mengenal pakaian adat dan rumah adat di Indonesia. Berfokus pada enam pakaian adat dan rumah adat yang ada di Jawa (secara acak). Menggunakan metode pengembangan multimedia dan pengembangan sistem.
Kendatipun terdapat perbedaan media dan materi komunikasi pengenalan, perancangan ini menampilkan kesamaan materi yaitu pakaian adat dan rumah adat yang juga berfokus pada bentuk pakaian dan rumah adat. Adapun perbedaan yang akan dirancang adalah perbedaan media utama yaitu video animasi 2D, materi yang difokuskan yaitu satu suku (suku Makassar).

Pengertian nama Makassar sebagai grup etnik, merupakan sekelompok masyarakat yang tinggal dan memiliki kebudayaan bersama yang disebut suku Makassar. Makassar mempunyai bahasa sendiri dengan berbagai dialek dan memiliki aksara yang disebut Lontara. Nama Makassar (mangkasarak) sebagai Ibu Negeri kerajaan Gowa, dijumpai dalam cerita rakyat Makassar yang dikaitkan dengan awal diterimanya agama Islam oleh raja Tallok. Raja berkesimpulan "nakbiya akkasarak" artinya Nabi menjelma atau menampakkan diri. Kemudian tempat Nabi ini dinamai mangkasarak atau Makassar (Lathief, 2014).

Stuktur sosial masyarakat Makassar dahulu dipengaruhi oleh sistem kerajaan/ kesultanan salah satu nya adalah kerajaan Gowa Tallo. Pengelompokan seperti golongan bangsawan, golongan merdeka/bebas dan orang baik, dan golongan budak/hamba (Saing, 2010). Pengelompokan ini sangat mempengaruhi tampilan bentuk pakaian adat dan rumah adat suku Makassar.

Pengertian Pakaian adat adalah pakaian beserta seluruh kelengkapannya yang dipakai oleh masyarakat di daerah tertentu. Rumah adat adalah rumah khas yang dimiliki dan digunakan sebagai tempat tinggal suku tersebut (2011). Penggunaan pakaian adat pada masyarakat Makassar dapat dibagi kedalam tiga jenis yaitu berdasarkan jenis kelamin (lakilaki dan perempuan), berdasarkan strata sosial (bangsawan, rakyat biasa dan budak) dan usia pemakainya (anak, remaja dan dewasa) dan berdasarkan penggunaannya (Tuti, 2013).

Penggunaan rumah adat juga dikelompokkan berdasarkan status sosial masyarakatnya seperti seperti balla lompoa adalah rumah besar yang didiami oleh keluarga kaum bangsawan. Rumah ini biasanya mempunyai ciri-ciri antara lain: berpetak lima atau tujuh, timpa laja (bubungannya) bersusun lima bagi raja berkuasa dan bersusun tiga bagi 
bangsawan lainnya. Mempunyai sapana, yaitu tangga beralas bertingkat di bagian bawah dengan atap diatasnya. Lalu ada Tarata, bentuknya lebih kecil dari Balla Lompoa, adalah rumah kediaman yang berpetak tidak lebih dari empat, tanpa sapana dan mempunyai bubungan yang bersusun satu atau tiga. Biasanya didiami oleh orang baik-baik, orang kaya atau orang berkedudukan dan terpandang dalam masyarakat. Terakhir ada balla merupakan rumah tempat kediaman masyarakat kebanyakan. Rata-rata berpetak tiga dan berbubungan lapis dua dan tidak mempunyai sapana (Saing, 2010).

Masyarakat Makassar mempunyai pandangan mengenai dunia (world view) dandapat disebut stuktur kosmos. Dimana manusia menganggap dirinya sebagai mikrokosmos atau bagian dari alam raya (makrokosmos) (Lathief, 2014). Pandangan tersebut menjadi falsafah dan pandangan hidup yang disebut "Sulapa appak". Paham Sulapa appak ini sangat berpengaruh dalam kehidupan masyarakat Makassar, menunjukkan usaha untuk menyempurnakan diri yang diajarkan turun temurun secara lisan. Kesempurnaan ini barulah terpenuhi jika memenuhi empat macam sifat yang dilambangkan juga dengan warna dan makna tertentu yaitu: api (merah berani), angin (kuning agung), air (putih suci) dan tanah (hitam gaib). Warna-warna tersebut banyak ditemukan pada atribut yang menghiasi rumah adat, bentuk kosmos (segi empat) juga terlihat pada bentuk tipologi rumah yang berbentuk segi empat panjang dan bentuk pakaian seperti baju dan sarung (Saing, 2010).

Animasi berasal dari bahasa latin "animare", yang artinya menghidupkan, mengisi dengan kehidupan, membuat menjadi hidup atau memberikan nyawa. Animasi juga dapat didefinisikan sebagai tampilan frame ke frame dalam urutan waktu untuk menciptakan ilusi gerakan yang berkelanjutan sehingga tampilan terlihat seolah-olah hidup atau mempunyai nyawa (Faizal Rochman dalam Hanadewi et al., 2020) Termasuk disiplin ilmu yang memadukan unsur seni dengan teknologi. Ada prinsip animasi yang mendasari dan teknologi berupa perangkat yang dapat merekam buah seni animasi tersebut (Soenyoto, 2017).

Penggunaan Animasi sekarang ini tidak hanya terbatas dalam penyampaian cerita lucu untuk anak atau dikenal dengan kartun, akan tetapi dapat juga dijadikan sebagai media pengenalan ataupun media informasi misalnya animasi untuk iklan, game dan sebagainya. Pembuatan animasi tersebut dibedakan berdasarkan tujuan pembuatannya dan terkadang penggunaan animasi digunakan untuk menambah kesan informasi sehingga terlihat meyakinkan (Faizal Rochman dalam Hanadewi et al., 2020)). Sehingga animasi dapat dijadikan sebagai media informasi atau media pengenalan yang menarik.

\section{METODE PENELITIAN}

Metode penelitian yang digunakan adalah metode kualitatif menggunakan teknik wawancara, dokumentasi dan observasi. Observasi dilakukan dengan pengamatan langsung terhadap objek materi pakaian adat dan rumah adat suku Makassar di Museum Balla Lompoa di Gowa dan Museum Kota Makassar. Di sana dilakukan wawancara dan dokumentasi pakaian adat dan rumah adat suku Makassar. Data dokumentasi berupa foto kegiatan observasi langsung berupa foto pakaian adat dan rumah adat suku Makassar dan observasi tak langsung berupa dokumentasi referensi yang ada di buku. Data studi pustaka berupa pembahasan dengan kata kunci suku.

Makassar, pakaian adat suku Makassar, rumah adat suku Makassar, dan animasi. Dimana data tersebut akan dicocokkan dengan hasil wawancara yang dilakukan. Bersifat melengkapi data yang telah tersedia. Pengumpulan data wawancara dilakukan dua kali yaitu pengumpulan data awal dilakukan pada Kepala Bidang Ekonomi Kreatif di Dinas Pasriwisata dan Kebudayaan mengenai perkembangan eksistensi pengetahuan pakaian adat dan rumah adat suku Makassar. Selanjutnya pada penelitian dilakukan wawancara dengan Bapak Andi Jufri AH, selaku staff ahli peneliti budaya Nusantara di Museum Balla Lompoa Gowa. Pertanyan yang diajukan berfokus pada materi yaitu pakaian adat suku Makassar meliputi bentuk, jenis, perlengkapan, makna filosofis dan rumah adat meliputi bentuk, jenis, perbedaan bentuk, bagian-bagian rumah, makna moral.

Dalam langkah pembuatan cerita dengan target anak-anak sebaiknya 
menggunakan konsep cerita yang jelas, sederhana, edukatif dan berakhir happy ending (Soenyoto, 2017). Maka dari itu untuk menyederhanakan penyampaian materi utama penulis akan berfokus pada 'bentuk' dari objek pakaian adat dan rumah adat suku Makassar. Materi tersebut saling terkait dan akan disampaikan secara sederhana, padat dan ringkas. Selain itu perancangan animasi ini bertujuan untuk mengenalkan materi pakaian adat dan rumah adat agar dapat meningkatkan ketertarikan anak untuk belajar mengenali pengetahuan tersebut. Salah satu unsur dalam animasi yang dapat menarik perhatian anak adalah penyampaian cerita. Informasi materi utama dipadukan dengan kisah atau cerita agar terlihat lebih menarik. Materi cerita tersebut merupakan materi pendukung, yang pada umumnya cerita animasi ditampilkan memiliki struktur seperti plot cerita, karakter/ tokoh, latar tempat, latar suasana, dan genre atau jenis cerita. Cerita tersebut dibangun menjadi satu kesatuan dalam bentuk naskah cerita.

Selanjutnya digunakan analisis matriks yang dilakukan terlebih dahulu untuk membandingkan media animasi dan media yang ada sebelumnya, dengan memperhitungkan kekurangan dan keunggulannya melalui analisis swot, untuk membuat suatu media baru yang lebih mengena (Soewardikoen, 2019). Dalam perancangan ini penulis menganalisa media cetak dan media audio visual sebagian media banding. Pada media cetak, media yang paling banyak dipakai adalah buku, baik berupa enslikopedia, buku sekolah, dan atlas. Merupakan media yang praktis dan mudah disimpan. Pada media tersebut, menampilkan informasi dan gambar akan materi. Akan tetapi terkadang tidak menampilkan informasi lengkap adalah solusi yang tepat dan gambar yang kecil sehingga sulit untuk dikenali. Pada media daring informasi biasa ditampilkan dalam bentuk artikel yang dirangkum dari buku maupun foto pakaian dan rumah adat yang ada di daerahnya.

Pada media audio visual, biasanya berupa video dan animasi. Video biasanya merupakan cuplikan dari museum ataupun taman nasional yang menyediakan replika dari pakaian dan rumah adat, maupun informasi berbentuk powerpoint. Pada animasi, biasanya menampilkan informasi dalam bentuk animasi
2D dan bergaya kartun, seperti pada Bloom dan Dongeng Kita. Dalam bentuk ini pengenalan menjadi lebih praktis, karena tidak perlu pergi kemanapun untuk mengenal materi dan disertai penyampaian informasi yang menarik. Akan tetapi, pada animasi terkadang menyampaikan informasi secara singkat dan cepat karena memiliki rentang durasi. Sehingga tidak menampilkan infromasi yang mendetail, dan terkadang sulit untuk mencari informasi yang telah terlewati dengan melihat durasi.

Berdasarkan analisa tesebut, maka penulis mengambil media audio visual berupa animasi sebagai media utama. Berdasarkan hasil penelitian terhadap pengaruh belajar menggunakan media audio visual tehadap hasil belajar siswa terbukti ada kenaikan yang cukup signifikan (Badruzaman dkk 2015: 127) dan pada penelitian pengaruh pemberian media animasi terhadap pengetahuan dan sikap siswa tentang gizi seimbang juga berpengaruh dan ada kenaikan diatas rata-rata (Lingga 2015: 62). Ditambah adanya kecenderungan anak yang menyukai kegiatan menonton, sehingga animasi.

Tabel 1. Matriks Perbandingan Media cetak dan Audio Visual

\begin{tabular}{|l|l|l|}
\hline & Media Cetak & Audio Visual \\
\hline Efektifitas & $\begin{array}{l}\text { Praktis dan } \\
\text { mudah } \\
\text { disimpan, } \\
\text { tidak } \\
\text { memerlukan } \\
\text { peralatan } \\
\text { khusus }\end{array}$ & ferbentuk \\
file \\
\hline Ilustrasi & $\begin{array}{l}\text { Gambar } \\
\text { diam, kecil } \\
\text { Penekanan } \\
\text { hanya pada } \\
\text { persepsi } \\
\text { indera } \\
\text { penglihatan }\end{array}$ & $\begin{array}{l}\text { Animasi } \\
\text { dengan } \\
\text { gambar } \\
\text { bergerak. } \\
\text { Penekanan } \\
\text { pada indera } \\
\text { penglihatan } \\
\text { dan } \\
\text { pendengaran }\end{array}$ \\
\hline
\end{tabular}

\section{HASIL DAN PEMBAHASAN Hasil}

Perancangan yang dilakukan adalah merancang sebuah media alternatif untuk 
mengenalkan anak tentang pakaian adat dan rumah adat Suku Makassar. Berikut merupakan hasil pengumpulan data yang telah didapatkan.

Tabel 2. Rangkuman Data Materi Pakaian dan rumah adat suku Makassar

\begin{tabular}{|c|c|c|}
\hline \multicolumn{3}{|c|}{$\begin{array}{c}\text { Rangkuman Data Materi Pakaian Adat Suku } \\
\text { Makassar }\end{array}$} \\
\hline 1 & $\begin{array}{l}\text { Bentuk } \\
\text { Pakaian Adat }\end{array}$ & $\begin{array}{l}\text { Berbentuk persegi } \\
\text { empat karena } \\
\text { masyarakat Makassar } \\
\text { menganut paham } \\
\text { kosmologi sulappa } \\
\text { appa yang menjadi satu } \\
\text { kesatuan. }\end{array}$ \\
\hline 2 & $\begin{array}{l}\text { Jenis- jenis } \\
\text { pakaian adat }\end{array}$ & $\begin{array}{l}\text { Memaparkan } \\
\text { mengenai jenis pakaian } \\
\text { berdasarkan jenis } \\
\text { kelamin (laki-laki dan } \\
\text { perempuan), } \\
\text { berdasarkan } \\
\text { penggunaannya } \\
\text { (sehari-hari dan } \\
\text { upacara/acara) dan } \\
\text { berdasarkan usia } \\
\text { pemakai (anak, remaja } \\
\text { dan dewasa) dan strata } \\
\text { sosialnya (bangsawan, } \\
\text { rakyat biasa dan hamba } \\
\text { sahaya). }\end{array}$ \\
\hline 3 & $\begin{array}{l}\text { Pehiasan } \\
\text { Sebagai } \\
\text { Kelengkapan } \\
\text { Pakaian Adat } \\
\end{array}$ & $\begin{array}{l}\text { Juga memaparkan } \\
\text { berdasarkan tiga } \\
\text { klasifikasi seperti } \\
\text { tersebut diatas. } \\
\end{array}$ \\
\hline 4 & $\begin{array}{l}\text { Penggunaan } \\
\text { Pakaian Adat }\end{array}$ & $\begin{array}{l}\text { Penggunaan pakaian } \\
\text { adat dalam berbagai } \\
\text { acara ataupun } \\
\text { kegiatan. } \\
\end{array}$ \\
\hline 5 & $\begin{array}{l}\text { Bahan dan } \\
\text { Cara } \\
\text { Pembuatan } \\
\text { Baju dan } \\
\text { Sarung } \\
\end{array}$ & $\begin{array}{l}\text { Bahan yang digunakan } \\
\text { dan cara pembuatan } \\
\text { baju adat Bodo } \\
\text { dan sarung (lipa'). }\end{array}$ \\
\hline 6 & $\begin{array}{l}\text { Makna } \\
\text { filosofi } \\
\text { Pakaian Adat }\end{array}$ & $\begin{array}{l}\text { Makna-makna yang } \\
\text { terkandung dalam } \\
\text { pakaian adat, makna } \\
\text { warna pada baju bodo, } \\
\text { dan perbedaan } \\
\text { penggunaan bahan } \\
\text { pada perhiasan } \\
\text { perlengkapan adat. }\end{array}$ \\
\hline \multicolumn{3}{|c|}{$\begin{array}{c}\text { Rangkuman Data Materi Rumah Adat Suku } \\
\text { Makassar }\end{array}$} \\
\hline 1 & & $\begin{array}{l}\text { Menjelaskan tentang } \\
\text { pengaruh kepercayaan } \\
\text { masyarakat suku }\end{array}$ \\
\hline
\end{tabular}

\begin{tabular}{|c|c|c|}
\hline & $\begin{array}{l}\text { Kosmologi } \\
\text { dan Arsitektur } \\
\text { Makassar }\end{array}$ & $\begin{array}{l}\text { Makassar terhadap } \\
\text { bentuk bangunan } \\
\text { rumah }\end{array}$ \\
\hline 2 & $\begin{array}{l}\text { Bentuk Rumah } \\
\text { Adat suku } \\
\text { Makassar }\end{array}$ & $\begin{array}{l}\text { Bentuk tampilan secara } \\
\text { keseluruhan bangunan } \\
\text { rumah adat suku } \\
\text { Makassar. }\end{array}$ \\
\hline 3 & $\begin{array}{l}\text { Bagian-Bagian } \\
\text { Rumah }\end{array}$ & $\begin{array}{l}\text { Menjelaskan bagian- } \\
\text { bagian rumah adat } \\
\text { beserta fungsinya: } \\
\text { bagian depan rumah } \\
\text { secara vertikal, } \\
\text { ruangan dalam rumah } \\
\text { secara horizontal, } \\
\text { beberapa ruang } \\
\text { tambahan dan } \\
\text { penjelasan bagian- } \\
\text { bagian rumah seperti } \\
\text { tiang, dinding, lantai } \\
\text { dan atap. }\end{array}$ \\
\hline 4 & $\begin{array}{l}\text { Tipe Rumah } \\
\text { Adat }\end{array}$ & $\begin{array}{l}\text { Menjelaskan tiga } \\
\text { macam rumah adat } \\
\text { suku Makassar. }\end{array}$ \\
\hline 5 & $\begin{array}{l}\text { Nilai Sosial } \\
\text { Budaya dalam } \\
\text { Rumah } \\
\text { Adat }\end{array}$ & $\begin{array}{l}\text { Perbedaan status sosial } \\
\text { masyarakat } \\
\text { membedakan bentuk } \\
\text { rumah adatnya } \\
\text { seperti pada bentuk } \\
\text { ukuran, tingkap/ } \\
\text { bubungan, bahan dan } \\
\text { ragam hias }\end{array}$ \\
\hline 6 & $\begin{array}{l}\text { Tata Cara } \\
\text { Pendirian dan } \\
\text { Menempati } \\
\text { Rumah Baru }\end{array}$ & $\begin{array}{l}\text { Menjelaskan proses } \\
\text { pendirian rumah dari } \\
\text { pemilihan bahan, } \\
\text { mendirikan tiang } \\
\text { hingga proses } \\
\text { mendiami rumah baru. }\end{array}$ \\
\hline 7 & $\begin{array}{l}\text { perubahan } \\
\text { yang terjadi } \\
\text { pada rumah } \\
\text { adat Suku } \\
\text { Makassar }\end{array}$ & $\begin{array}{l}\text { Tradisi pembuatan } \\
\text { rumah panggung } \\
\text { dikalangan suku } \\
\text { Makassar masih tetap } \\
\text { berlangsung hingga } \\
\text { sekarang. }\end{array}$ \\
\hline 8 & $\begin{array}{l}\text { Makna } \\
\text { filosofis rumah } \\
\text { adat }\end{array}$ & $\begin{array}{l}\text { Makna yang } \\
\text { terkandung dalam } \\
\text { ornamen atau ragam } \\
\text { hias yang ada di rumah } \\
\text { Suku adat Makassar }\end{array}$ \\
\hline
\end{tabular}

Berdasarkan masalah yang diangkat media yang ditampilkan kurang menarik minat anak untuk mempelajari materi tersebut. Maka dirancanglah sebuah media alternatif yang berisi kegiatan yang disukai anak yaitu menonton melalui sebuah media yang menarik yaitu video animasi. Animasi berdurasi 8.31 menit dan ditampilkan dengan gaya ilustrasi 
kartun, dengan konsep warna menggunakan warna cerah (Bright Color) yang ditampilkan penuh warna. Penggunaan warna cerah untuk menimbulkan kesan keceriaan dalam petualangan, menyesuaikan konsep desain dan visual branding yang diangkat. Warna dominannya adalah warna panas merah, kuning, orange dan coklat. Animasi tersebut ditampilkan dengan warna- warna yang cerah dan bentuk gambar yang lucu untuk meningkatkan ketertarikan anak dalam menonton video animasi ini.

\section{Media Utama}

Materi utama dalam animasi ini ditampilkan dengan konsep 'ikon' yang mengacu pada bentuk pakaian dan perhiasan adat bertema cerita petualangan. Cerita yang ditampilkan bergenre slice of life (keseharian) dan fantasi. Mengangkat cerita tentang keseharian untuk memberikan kesan kedekatan anak dengan materi, sehingga anak akan merasa pernah mengalami cerita tersebut. Selain itu tema cerita petualangan juga merupakan perwakilan salah satu kegiatan bermain anak, sumber inspirasi yang berasal dari lingkungan tinggal masyarakat Makassar, penggunaan narasi berdialek Makassar dan metari komunikasi mengenai budaya suku Makassar (pakian adat dan rumah adat) tentu dengan tujuan yang sama yaitu memberikan nuansa kedekatan anatara materi dengan anak (penonton).

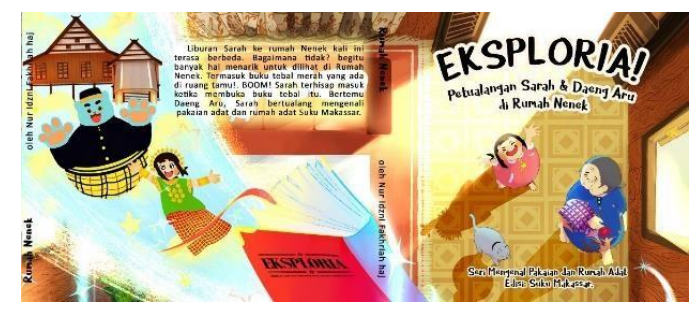

Gambar 1. Sampul Depan DVD

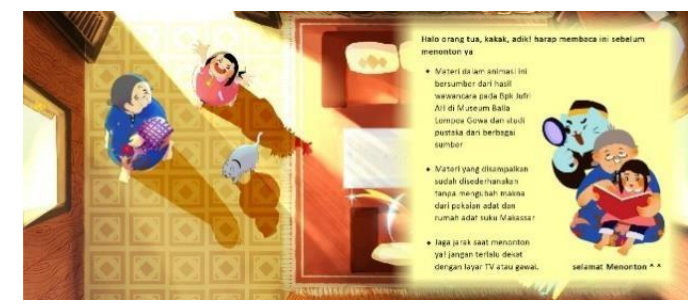

Gambar 2. Sampul Belakang DVD

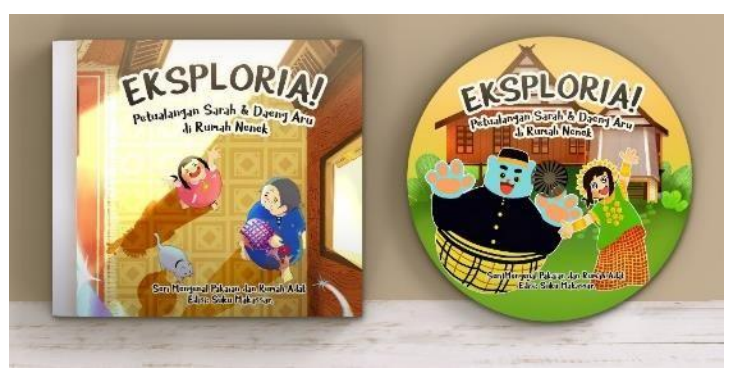

Gambar 3. Tampilan Wadah dan Label DVD

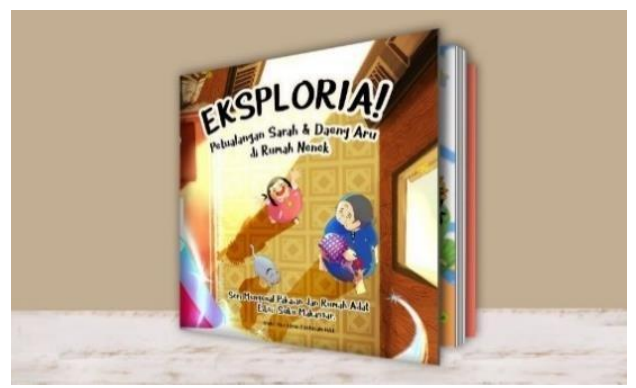

Gambar 4. Tampilan Buku Cerita

Materi yang ditampilkan yaitu bentuk pakaian adat dan rumah adat, jenis-jenis pakaian adat dan rumah adat, perhiasan yang melengkapi pakaian adat, makna warna pada pakaian adat dan nilai sosial budaya yang terkandung dalam rumah adat. Pemilihan materi tersebut mengacu pada batasan masalah yang telah ditetapkan yaitu lebih berfokus untuk menjelaskan bentuk pakaian adat dan rumah adat. Selain itu juga untuk lebih menyederhanakan penyampaian materi agar lebih mudah diterima oleh anak, sehingga tidak menurunkan ketertarikan anak untuk mengenal materi yang akan disampaikan. Penulis juga merancang media pendukung seperti wadah untuk menyimpan DVD, karena berdasarkan analisis SWOT yang dilakukan DVD rentan rusak jika sering tergores, selain itu dirancang juga sampul DVD yang menampilkan informasi mengenai sinopsis cerita animasi. Selain itu juga ditambahkan media pendukung seperti buku cerita untuk memudahkan anak meninjau kembali materi yang telah disampaikan di video dan untuk tetap mengenalkan literasi kepada anak. Buku cerita ini berisi rangkuman keseluruhan cerita dalam video animasi. Media promosi juga penulis buat untuk mempromosikan animasi ini, seperti poster, X-Banner dan Merchandise 
untuk menambah ketertarikan target audience terhadap animasi ini.

Perancangan media animasi ini tentu dapat diimplementasikan kepada masyarakat karena selain merupakan media edukasi yang menarik (animasi), kegiatannya (menonton) juga disukai oleh orangtua dan anak. Secara teoretis perancangan ini juga mengikuti kajian pustaka yang telah dipaparkan meskipun ada beberapa bagian yang dilewatkan karena bentuk animasi yang dirancang hanya berupa limited animasi (pengulangan animasi dan pemaikan prinsip yang lebih sedikit), SDM yang lebih sedikit dan ada langkah yang sudah tergabung dalam satu kali proses kerja. Melalui perancangan animasi ini diharapkan dapat meningkatkan ketertarikan anak dalam mengenal dan mempelajari pakaian adat dan rumah adat Suku Makassar.

\section{Media Promosi}

Media pendukung dalam perancangan ini berupa DVD, sampul label kover DVD dan buku cerita. Sampul DVD digunakan untuk menyampaikan informasi tambahan, berukuran 12x26 cm (depan belakang) dan berbahan kinstruk 150gr. Informasi yang ditampilkan judul Eksploria! yang berbentuk logotype, sinopsis cerita animasi, nama pengarang, informasi mengenai sumber data yang digunakan dan instruksi sebelum menonton pada bagian dalam sampul. Label DVD berbahan kertas stiker ukuran $12 \times 12 \mathrm{~cm}$. Label akan dipasang di kepingan DVD. Wadah DVD berbahan akrilik bening dan berukuran $14,1 \times 12 \mathrm{~cm}$. Hasil video animasi dirender menggunakan aplikasi Nero kedalam kepingan DVD. Terakhir adalah media buku cerita, berisi keseluruhan cerita pada video animasi yang ditampilkan kedalam bentuk buku. Berukuran 20x20 cm dengan bahan kertas hvs $80 \mathrm{gsm}$ dengan isi 12 halaman timbal balik, teknik cetak digital printing. Penggunaan media buku selain untuk memudahkan anak dalam melihat kembali materi yang telah disampaikan juga berfungsi untuk tetap mengenalkan literasi kepada anak.

Media promosi perancangan ini berupa poster, X-Banner dan merchandise. Poster berukuran A3 $(29,7 \times 42 \mathrm{~cm})$ dan berbahan kinstruk 260gr. X-Banner berukuran 160x60 $\mathrm{cm}$ berbahan Albatros. Informasi yang ditampilkan pada poster dan X-Banner berupa ajakan untuk mengikuti (melihat) petualangan Sarah dalam mengenali pakaian adat dan rumah adat Suku Makassar. Adapun Merchandise yang dibuat yaitu gantungan kunci berbahan akrilik ukuran

$6 x 6 \mathrm{~cm}$, stiker berbahan glossy stiker berukuran $12 \times 15 \mathrm{~cm}$, tumbler berbahan plastik food grade berukuran $10 \times 18 \mathrm{~cm}$ berwarna merah untuk mewakili karakter Sarah dan warna biru untuk mewakili karakter Nenek dan Aru, totebag dengan bahan kain drill premium ukuran 30x40 cm. Penggunaan Merchandise totebag sebagai promosi berupa penjualan berpaket yang di dalamnya tersedia media utama dan pendukung serta merchandise.

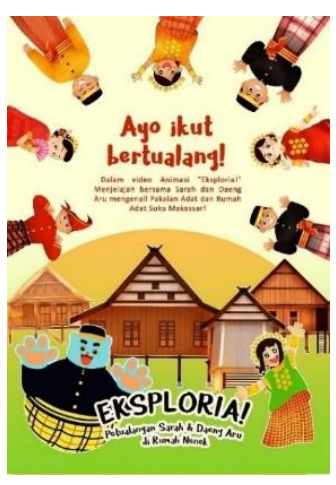

Gambar. 5 Media Promosi Poster

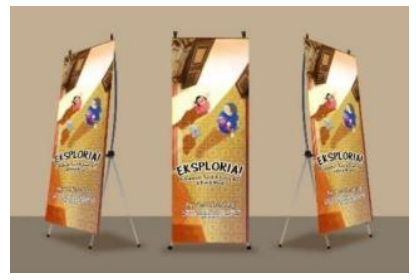

Gambar 6. Media Promosi X-Banner

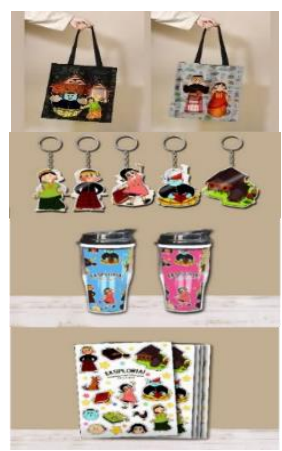

Gambar.7 Media Promosi Merchandise (Totebag, Gantungan kunci, Tumbler/ Botol Minuman dan Stiker) 


\section{Pembahasan}

Media utama dalam perancangan ini adalah video animasi edukasi yang bercerita tentang petualangan karakter Sarah dan Daeng Aru mengenal pakaian adat dan rumah adat edisi Suku Makassar. Animasi ini dapat dijadikan serial dengan materi suku yang berbeda, sehingga pada sampul dan label juga menampilkan kata 'seri petualangan' dan 'edisi' untuk meunjukkan fokus materi yang disampaikan.

Animasi ini berjudul 'Eksploria! Petualangan Sarah dan Daeng Aru di Rumah Nenek' dengan konsep desain keceriaan dalam petualangan, dengan materi yang mengacu pada bentuk dengan menampilkan ikon pakaian adat, perhiasan adat dan tema cerita petualangan fantasi. Konsep ikon dipilih untuk menyesuaikan dengan konsep materi pesan yang sederhana, ringkas dan berfokus pada bentuk dari materi tersebut, juga untuk memudahkan anak mengingat bentuk dari ikon yang ditampilkan.

Sedangkan mengangkat tema petualangan karena merupakan salah satu kegiatan bermain yang disukai anak-anak. Video animasi ini berbentuk 2D dengan hasil akhirnya berupa limited animation (pergerakan animasi terbatas sekitar 6-8 frame). Video animasi berdurasi 8.31 menit dengan ukuran full HD (1980x1080px) resolusi 300 dpi, format MP4.

Proses pembuatan animasi dimulai dengan menentukan materi yang akan disampaikan yaitu pakaian adat dan rumah adat Suku Makassar. Materi tersebut lalu disederhanakan dan dipadukan dengan konsep visual yang telah ditetapkan menjadi sebuah naskah cerita. Setelah itu naskah cerita tersebut dipaparkan kedalam thumbnail dan storyboard. Sementara proses tersebut berjalan juga dilakukan pre-recording (rekaman dialog). Setelah proses tersebut selesai maka dimulailah tahap digitalisasi karakter dan latar yang telah dipisahkan perbagian (yang ingin dianimasikan dan tidak). Proses digitalisasi bertahap dari lineart hingga pewarnaan. Hasil karakter yang telah didigitalisasikan lalu dimasukkan kedalam aplikasi Adobe After Effect untuk digerakkan menggunakan teknik puppet pintool, pada tahap ini juga dimasukkan hasil rekaman untuk menyesuaikan gerakan animasi. Setelah semua proses pergerakan karakter dan latar selesai, maka dilakukan editing dengan penambahan sound effect dan instrumen untuk meningkatkan suasana. Hasil tersebut lalu dilakukan rendering menjadi file video animasi. Berikut merupakan penjelasan tiap scene media utama yang dihasilkan dari perancangan.

Tabel 4. Penjelasan Perbagian Scene Animasi

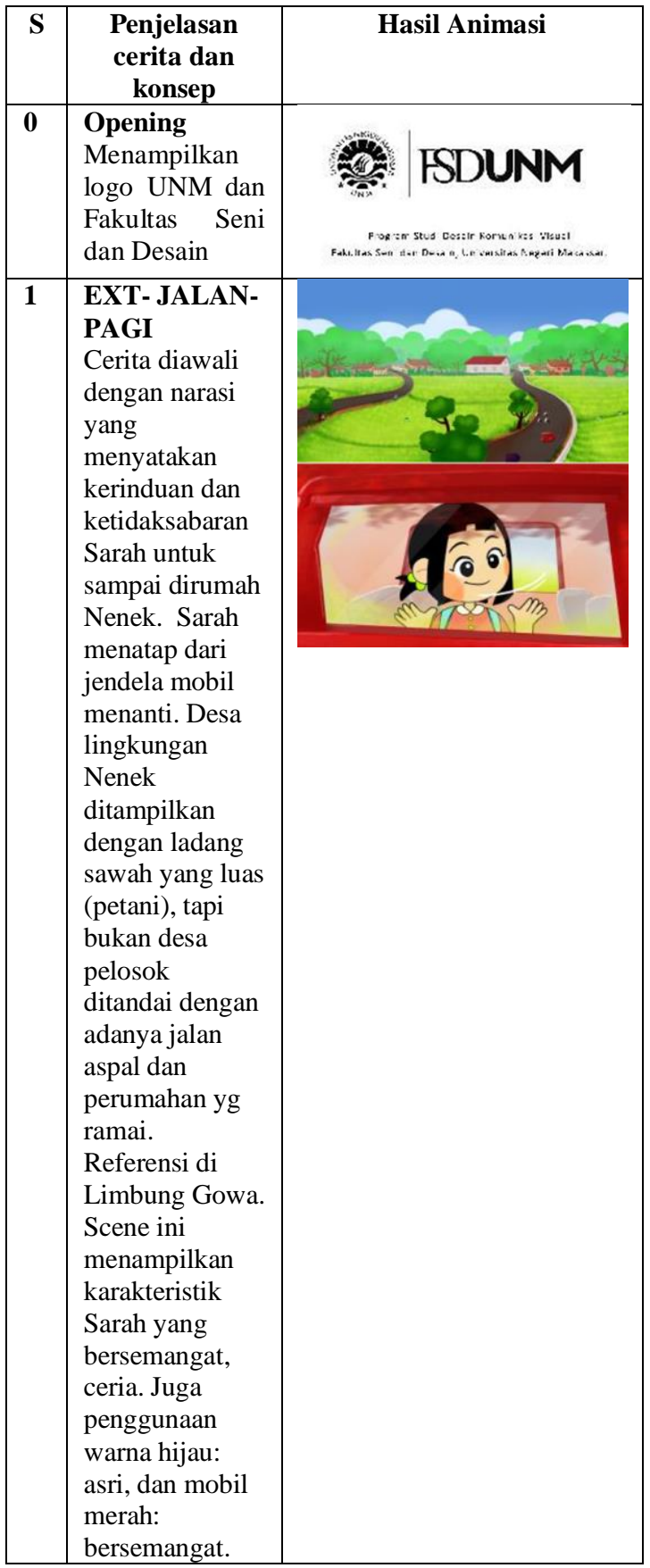




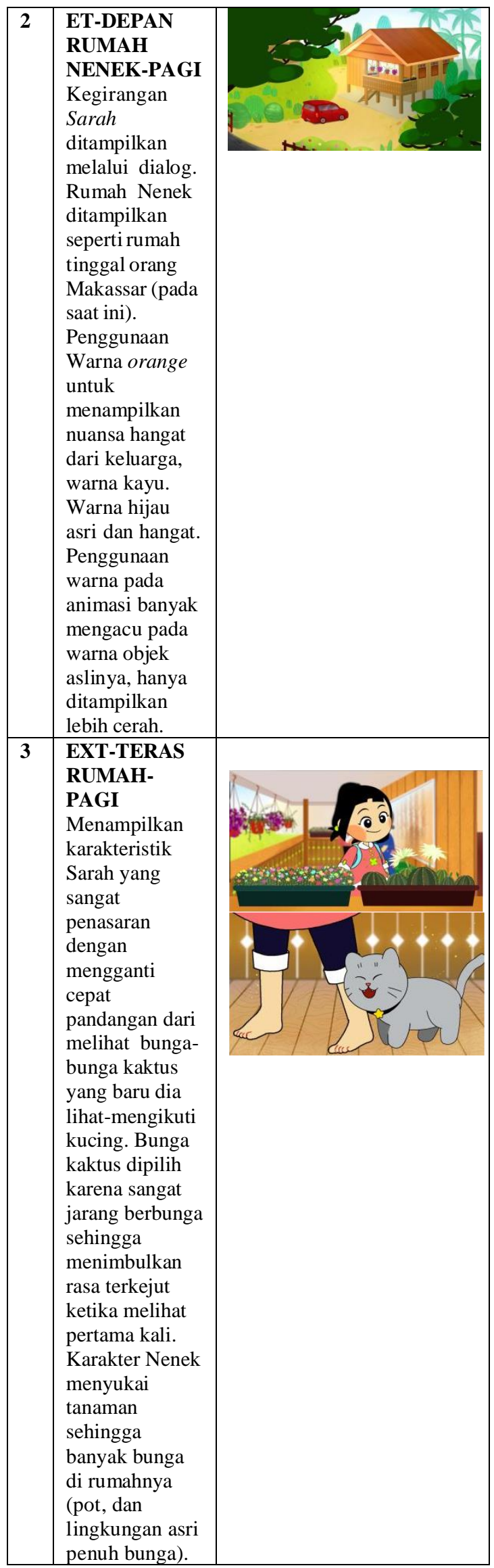

\begin{tabular}{|c|c|c|}
\hline & $\begin{array}{l}\text { Tampilan pagar } \\
\text { berbentukegi } \\
\text { empat, karena } \\
\text { Nenek masih } \\
\text { menyakini } \\
\text { paham sulappa } \\
\text { appa. }\end{array}$ & \\
\hline 4 & $\begin{array}{l}\text { INT-RUANG } \\
\text { TAMU-PAGI } \\
\text { Awal mula } \\
\text { perjalanan } \\
\text { fantasi dimulai. } \\
\text { Disini Sarah } \\
\text { kaget melihat } \\
\text { kilau cahaya yg } \\
\text { ternyata berasal } \\
\text { dari dalam } \\
\text { buku. }\end{array}$ & $\frac{13}{3}$ \\
\hline & $\begin{array}{l}\text { Buku Eksploria } \\
\text { ini merupakan } \\
\text { buku kakek } \\
\text { (alm). terlihat } \\
\text { rak yang penuh } \\
\text { dengan buku } \\
\text { dan beberapa } \\
\text { figura } \\
\text { terpajang. } \\
\text { Terlihat tidak } \\
\text { logis karena } \\
\text { buku itu seperti } \\
\text { muncul sendiri. } \\
\text { Nyatanya Sarah } \\
\text { sedang } \\
\text { bermimpi } \\
\text { setelah } \\
\text { membaca buku } \\
\text { yang memang } \\
\text { ada diatas meja. } \\
\text { Dan mimpinya } \\
\text { terulang dari } \\
\text { pertama kali dia } \\
\text { datang ke } \\
\text { rumah Nenek. }\end{array}$ & \\
\hline 5 & $\begin{array}{l}\text { EXT-DUNIA } \\
\text { EKSPLORIA- } \\
\text { SIANG } \\
\text { Sarah masuk } \\
\text { ke Eksploria. } \\
\text { Ditampilkan } \\
\text { seperti } \\
\text { terminal } \\
\text { kedatangan atau } \\
\text { terminal } \\
\text { menunggu } \\
\text { kendaraan. } \\
\text { Karena setelah } \\
\text { ini Sarah akan } \\
\text { melakukan } \\
\text { perjalanan } \\
\text { bertualang } \\
\text { dengan Daeng } \\
\text { Aru (karakter }\end{array}$ & (4) \\
\hline
\end{tabular}



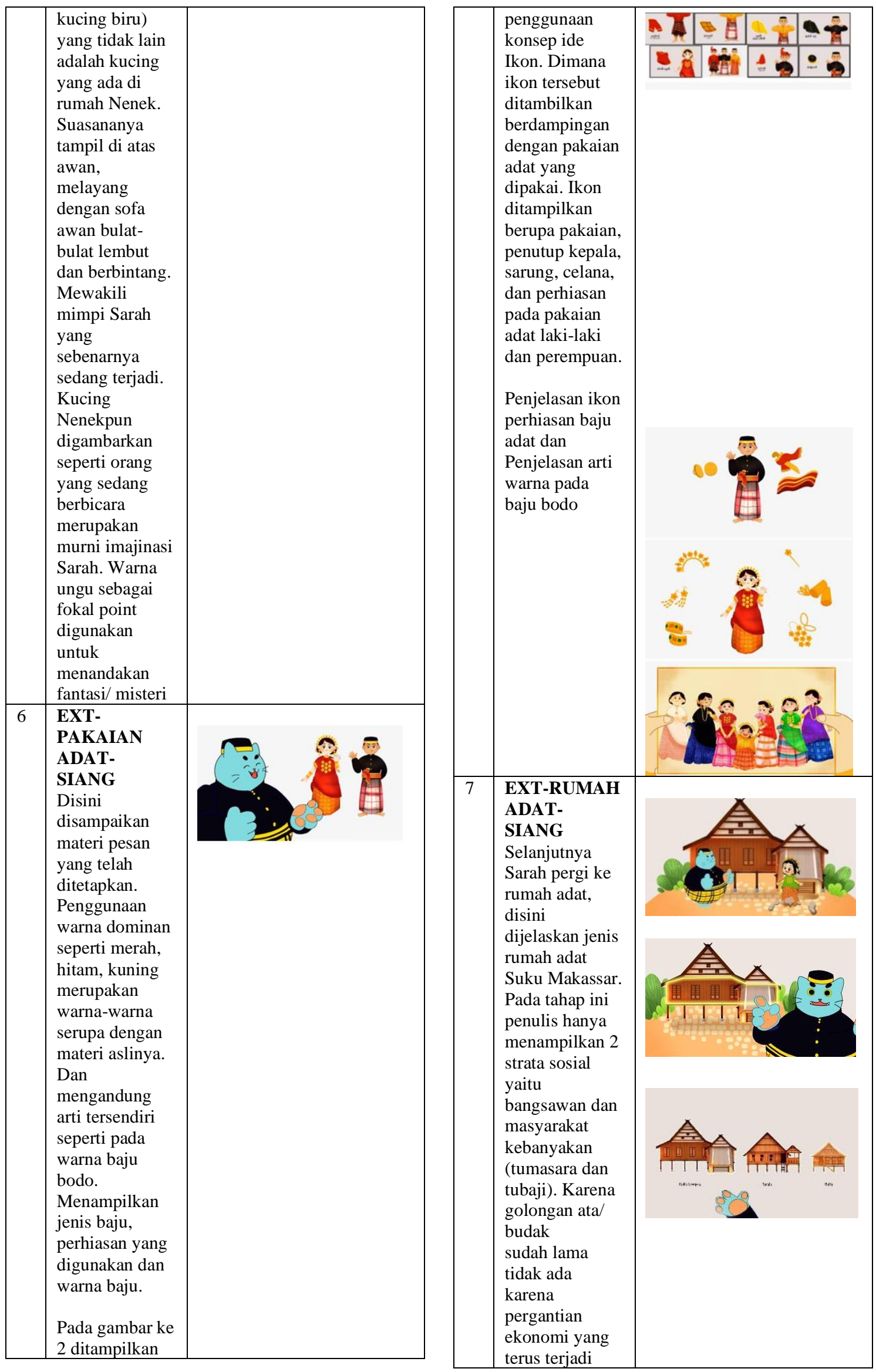


\begin{tabular}{|c|c|c|}
\hline & $\begin{array}{l}\text { (dan dapat } \\
\text { berkembang). } \\
\text { Penamaan jenis } \\
\text { rumah } \\
\text { taratapun } \\
\text { sebenarnya } \\
\text { sudah lama } \\
\text { tidak dipakai, } \\
\text { hanya berupa } \\
\text { balla lompoa } \\
\text { (rumah besar) } \\
\text { dan balla } \\
\text { (rumah } \\
\text { masyarakat } \\
\text { kebanyakan). } \\
\text { Tapi tetap } \\
\text { ditampilkan } \\
\text { agar tidak } \\
\text { membingungka } \\
\text { n penyebutan } \\
\text { nama rumah } \\
\text { yang sama. } \\
\text { Selain itu tidak } \\
\text { ditampilkan } \\
\text { materi } \\
\text { mengenai strata } \\
\text { sosial Suku } \\
\text { Makassar yang } \\
\text { lebih dalam } \\
\text { hanya sebagai } \\
\text { perwakilan } \\
\text { untuk } \\
\text { membedakan } \\
\text { bentuk rumah. }\end{array}$ & \\
\hline 8 & $\begin{array}{l}\text { EXT- } \\
\text { EKSPLORIA- } \\
\text { SORE } \\
\text { Perjalanan } \\
\text { Sarah sudah } \\
\text { selesai. Mereka } \\
\text { telah sampai di } \\
\text { ujung } \\
\text { Eksploria. } \\
\text { Suasana } \\
\text { berubah } \\
\text { menjadi } \\
\text { kekuningan } \\
\text { mewakili waktu } \\
\text { yang terus } \\
\text { berjalan } \\
\text { (menandakan } \\
\text { lama tidur } \\
\text { Sarah). Perut } \\
\text { Sarah } \\
\text { sudah lapar } \\
\text { karena belum } \\
\text { makan siang. }\end{array}$ & 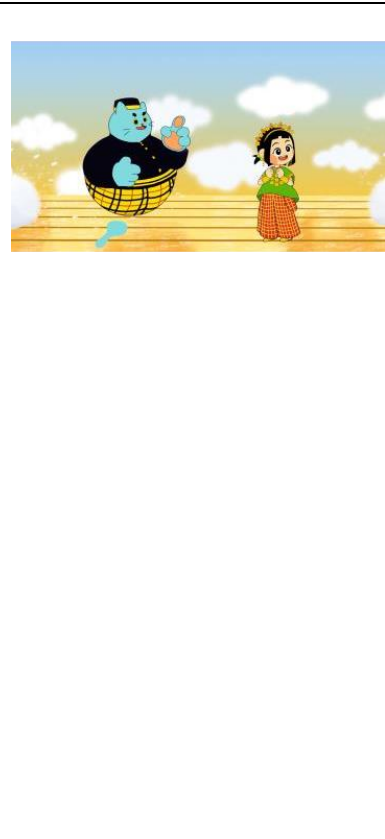 \\
\hline 9 & $\begin{array}{l}\text { INT-RUANG } \\
\text { TAMU-SORE } \\
\text { Terlihat Sarah } \\
\text { tertidur pulas }\end{array}$ & \\
\hline
\end{tabular}

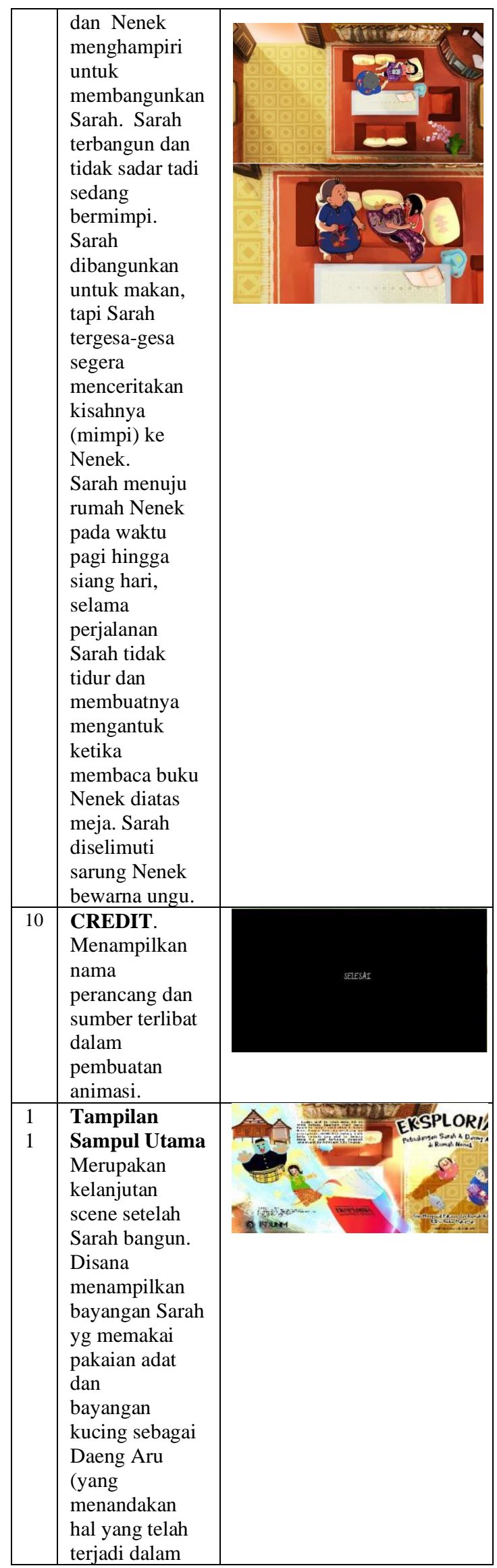




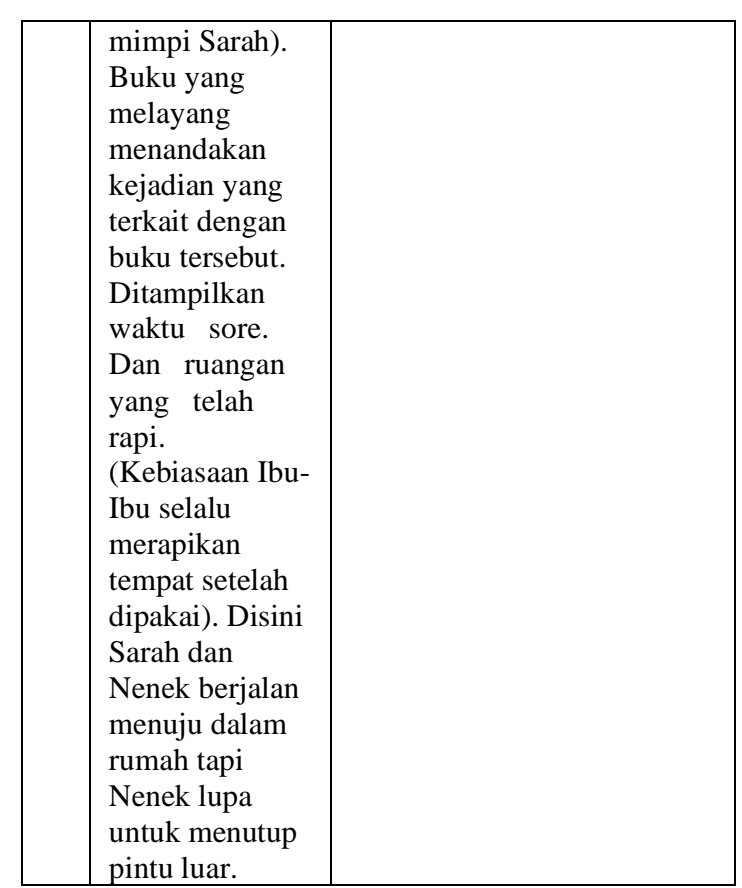

\section{KESIMPULAN DAN SARAN}

Pengenalan budaya sejak dini memang sangat penting untuk dilakukan sebagai upaya meningkatkan minat anak dalam mengenal budaya yang ada di sekitarnya. Begitu pula dengan pakaian adat dan rumah adat Suku Makassar. Akan tetapi, media yang ditampilkan terkadang menurunkan ketertarikan anak sehingga masih ada anak yang tidak mengenal budayanya. Oleh karena itu, dibutuhkan media yang dapat meningkatkan ketertarikan anak untuk mengenali budaya pakaian adat dan rumah adat Suku Makassar. Salah satu cara meningkatkan minat anak dalam mengenal sesuatu adalah dengan menggabungkan kegiatan yang anak sukai dengan materi yang ingin dikenalkan atau diajarkan, misalnya dengan kegiatan menonton melalui media yang menarik seperti video animasi.

Adapun perancangan animasi untuk pengenalan pakaian adat dan rumah adat Suku Makassar ini menghasilkan media utama berupa video animasi yang berjudul 'Eksploria! Petualangan Sarah dan Daeng Aru di Rumah Nenek'. Animasi tersebut ditampilkan dengan konsep keceriaan dalam petualangan dan berfokus pada 'Ikon' yang mengacu pada bentuk pakaian dan perhiasan adat, cerita bertema petualangan di dunia mimpi dengan materi yang disederhanakan dan ditargetkan kepada anak berusia 9-10 tahun. Hasil perancangan Animasi ini diharapkan mampu menjawab masalah dan tujuan perancangan yaitu menjadi media alternatif yang dapat meningkatkan ketertarikan anak dalam mengenal pakaian adat dan rumah adat Suku Makassar. Juga sebagai pengenalan budaya Suku Makassar kepada masyarakat luar pulau Sulawesi.

Selain media utama berupa video animasi juga didukung dengan media pendukung seperti DVD, label, sampul, wadah DVD dan buku cerita, juga disertai media promosi seperti poster, X-Banner dan merchandise. Terlepas dari keterbatasan yang dimiliki perancangan ini diharapkan mampu menjawab permasalah dengan menciptakan sebuah media alternatif untuk mengenalkan anak dalam mengenali pakaian adat dan rumah adat suku Makassar. Adapun saran terhadap media perancangan yang dapat dijadikan acuan untuk peneliti/perancang selanjutnya adalah sebagai berikut:

1. Tampilan karakter Daeng Aru sebagai roh kucing yang berbicara mungkin akan membuat beberapa anak merasa tidak nyaman. Terlebih jika anak tersebut takut dengan kucing. Disarankan untuk perancang selanjutnya lebih jeli memperhatikan psikografis target audiens sebagai pertimbangan dalam penggambaran karakter utama cerita.

2. Informasi yang disampaikan terbatas pada 'bentuk' pakaian adat dan rumah adat sukuMakassar dengan pertimbangan materi yang disampaikan akan lebih sederhana dan memudahkan anak untuk mengenal dan mengingat materi tersebut. Maka akan lebih baik jika perancang selanjutnya mempertimbangkan materi tersebut untuk dipisahkan ataupun menambahkan serial dari pembahasan yang sudah ada (pakaian adat, rumah adat). Sehingga pembahasan pada satu objek materi juga jadi lebih banyak (tidak terfokus pada bentuk saja) walaupun disampaikan secara sederhana dan ringkas.

3. Animasi ini diposisikan sebagai serial berbentuk short movie, sehingga perancangan selanjutnya dapat menggunakan kembali karakter, tema dan branding dengan fokus materi suku yang 
berbeda. Adapun suku yang diutamakan adalah suku di pulau Sulawesi, dimana karakter utama memang mengacu pada lingkungan masyarakat Makassar (Sulawesi Selatan). Sehingga unsur seperti bentuk karakter masih memiliki kedekatan dengan materi yang akan ditampilkan. Adapun penggunaan karakter dan branding diluar pulau Sulawesi juga dapat dilakukan, hanya saja diperlukan pengurangan maupun penambahan branding yang disesuaikan kembali dengan perancangangan yang akan dilaksanakan.

\section{DAFTAR PUSTAKA}

Asy'ari, Mintarti, S., Syarifudin, M., Syafrida, I., Agung, S., Faisal, Valentino, D., Azis, M., Riyadi, Y.N., 2011. Next Step IPS Aktif 4: Untuk Sekolah Dasar Kelas IV, 2011th ed. Esis, Erlangga, 2011, Jakarta.

Caprisa, N., 2020. PERANCANGAN AUGMENTED REALITY RUMAH ADAT SULAWESI SELATAN (PhD Thesis). Fakultas Seni dan Desain.

Hanadewi, A., Rahardjo, S., Purnomo, A.D., 2020. Perancangan Studio Kreatif Animasi Di Jakarta. EProceedings Art Des. 7.

Kusherdyana, S.D., 2013. Statistik Pariwisata. Bdg. Alf.

Lasapu, P.B., Bramantya, B., Sutanto, R.P., 2015. Perancangan Media Pembelajaran Interaktif Tentang Pakaian Adat Dalam Bentuk Boneka Tangan Untuk Anak Usia 6-8 Tahun. J. DKV Adiwarna 1, 20.

Lathief, H., 2014. Orang Makassar. Yogyakarta: Padat Daya.

Saing, A.M., 2010. Arsitektur Tradisional Rumah Adat Bugis Makassar. Makassar Indhira Art.

Soenyoto, P., 2017. Animasi 2D. Elex Media Komputindo.

Soewardikoen, D.W., 2019. Metodologi Penelitian: Desain Komunikasi Visual. PT Kanisius.

Sugiyanto, S.S., 2011. GAME EDUKASI RAGAM BUDAYA SEBAGAI MEDIA PEMBELAJARAN BUDAYA TENTANG PAKAIAN
DAN RUMAH ADAT DI

INDONESIA. Semantik 1.

Tuti, T., 2013. Konsep Warna Baju Bodo. J. Ilmu Komun. 3. 